DOI: https://doi.org/10.31933/dijemss.v3i2

Received: 10 November 2021, Revised: 15 December 2021, Publish: 25 January 2022

\begin{tabular}{|c|c|c|}
\hline DINASTISH & $\begin{array}{l}\text { DIJEMSS } \\
\text { DINASTI INTERNATIONAL JOURNAL } \\
\text { OF EDUCATION MANAGEMENT AND } \\
\text { SOCIAL SCIENCE }\end{array}$ & $\begin{array}{r}\text { https://dinastipub.org/DIJEMSS } \\
\text { editor@dinastipub.org } \\
08117401455 \square\end{array}$ \\
\hline
\end{tabular}

\title{
SUPPORTING SUPERIOR COMPETENCY OF LECTURERS FOR EXCELLENT PERFORMANCE OF LECTURERS OF MANAGEMENT S1 STUDY PROGRAM AT A PRIVATE UNIVERSITY IN BANDUNG METROPOLITAN
}

\section{Saptono Kusdanu Waskito}

D IV Business Logistics Study Program Pos Indonesia Polytechnic, Bandung

Corresponding Author: saptonokw@yahoo.com

\begin{abstract}
Bandung Metropolitan has Private Universities that have Management Study Programs with $\mathrm{A}$ accreditation as many as 5 universities, while 8 other private universities $(61.53 \%)$ only have $\mathrm{B}$ and $\mathrm{C}$ accreditations. This information shows that there is a problem with the organizational performance of the Management Study Program. Wirawan ( 2020) explains that organizational performance is influenced by individual performance. Based on Wirawan's opinion, the author conducted research on the performance of the Management S1 Study Program lecturers. Yuniarsih (2017) explains that superior performance is influenced by individual superior competence. Armed with the opinion of Wirawan (2020) and Yuniarsih (2017) the authors conducted research on the influence of superior competence of lecturers on superior performance of lecturers in the Management Study Program of Private Universities in Bandung Metropolitan. The total population is 404. A sample of 201 is determined by the Slovin formula. Research proves that there is a positive and significant influence of superior competence on superior performance of lecturers, with an estimate value of 0.640 and a probability value of 0.000 $<0.05$. If you want to improve the superior performance of lecturers, what must be improved first is the superior competence of lecturers, by improving the dimensions of competence pedagogic. Improvement of pedagogic competence is carried out by improving the way of communicating with students, as well as improving skills using teaching and learning process methods that are in accordance with the online learning process. The superior performance of lecturers is improved by improving the dimensions of community service performance. Improvements in community service are carried out by solving problems in the lecturer village, presented in the community service report. Servant The Community Report is presented in the community service journal.
\end{abstract}

Keyword: Superior Competence, Superior Performance, Lecturer, Management S1 Study Program, Private University, Bandung Metropolitan

\section{INTRODUCTION}

Bandung Metropolitan is a newly introduced term for the area of Bandung City, Bandung Regency, West Bandung Regency, Cimahi City and Sumedang Regency. Currently in Bandung Metropolitan there are 13 Private Universities that have Management Study Programs. There are 5 Universities in A-accredited Management Study Programs, 5 B-accredited Universities and 3 C-accredited Universities. In 
Sumedang Regency there are no private universities (APTISI, 2021). Suharsaputra (2021: 5) explains that accreditation is the government's acknowledgment of the performance of the Management Study Program. Ideally the accreditation of each Study Program A, if there are 5 Study Programs accredited B as many as 5 Study Programs, and accreditation $\mathrm{C}$ as many as 3 people, it means that there are 8 Management Study Programs $(61.53 \%)$ that are not in line with expectations, meaning that there are still problems with performance of the Management Study Program at a Private University in Greater Bandung.

Wirawan (2020:7) explains that organizational performance (Study Program Performance) is influenced by individual performance (superior performance of lecturers). Taking into account Wirawan's opinion (2020:7), the author is interested in conducting research on the superior performance of Management Study Program lecturers at Private Universities in Bandung Raya. Yuniarsih (2017:10) explains that the superior performance of the lecturer is influenced by the competence of the lecturer. Paying attention to Yuniarsih's opinion (2017:10) the author is interested in doing lecturer competence.

Taking into account the opinions of Wirawan (2020: 7) and Yuniarsih (2017: 10), the author wants to prove the influence of superior competence of lecturers on superior performance of lecturers in the Management Study Program at Private University in Bandung Metropolitan

\section{LITERATURE REVIEW}

\section{Lecturer Superior Competence}

Lecturer Superior Competence according to Yuniarsih (2017:45) is the ability of a lecturer to do something efficiently and effectively. Lecturer Superior Competencies according to Waskito (2021:29) are knowledge, attitudes, skills, sincerity, humility that a person has in order to complete work quickly, precisely, without mistakes. Superior competence of lecturers has dimensions consisting of pedagogic competence, professional competence, competence personal competence, social competence, research competence, publication competence, digital competence. Understanding the definition of experts regarding superior competence can be explained that superior competence is a collection of knowledge, skills, attitudes, sincerity, humility that a person has manifested in work and is used to achieve performance superior. Dimensions of superior competence of lecturers are pedagogic competence, professional, personal, social, research, research publications, and digital competence.

The superior competence of lecturers consists of several dimensions, including pedagogic competence, professional competence, personal competence, social competence, research competence, publication competence, and digital competence. (Waskito, 2021:30)

\section{Lecturer Superior Performance}

Lecturers according to Waskito (2019: 120) are professional educators and scientists with the main task of transforming, developing, and disseminating science and technology through education, research and community service. According to Suharsa in Waskito (2019:122) Lecturer performance or the work of Lecturers which must be seen in the context of the main tasks of the tridharma of higher education (teaching, research, and community service as well as supporting tasks of the tridharma of higher education). Kustono in Waskito (2019: 123) explains that lecturer performance is the workload of lecturers that must be carried out by lecturers when carrying out tasks education and 
teaching, research, community service and when carrying out supporting tasks (Structural) the tridharma of higher education

Yuningsih (2017:11) outlines his idea that the performance of superior lecturers is the achievement of individual work targets optimally. Superior performance of lecturers according to Waskito (2019:122) is the workload of lecturers that must be carried out by lecturers when carrying out educational and teaching tasks, research, community service as well as when carrying out supporting tasks (Structural) of the Tridharma of Higher Education. Taking into account the opinions of experts, it can be explained that the performance of superior lecturers is the result of the work of lecturers in accordance with those targeted in the objectives of the study program. Dimensions of Superior Lecturer Performance according to Kustono in Waskito (2019:123) are teaching performance, research performance, community service performance. In this study, many lecturers have structural positions, so the dimensions of carrying out supporting tasks (structural) are not examined in this study.

\section{The Effect of Superior Competence on Lecturer Superior Performance}

Wirawan (2020:7) explains that individual performance is influenced by individual competence. Yuniarsih (2017:10) explains that the superior performance of lecturers is influenced by lecturer competence.

\section{RESEARCH METHODS}

The author in this study applied quantitative, descriptive and verification research methods. Quantitative research is research in the form of respondents' perceptions which are still qualitative and then converted into quantitative figures. Descriptive research is a research that explains the average value of the variable superior competence of lecturers and superior performance of lecturers. Verificative research wants to prove the influence of superior competence of lecturers on superior performance of lecturers

Types and Sources Of Data

The data used in this study is interval data with reference to the Likert scale (Waskito, 2020: 15). The scores of 1 (strongly disgree), 2 (disagree), 3 (neutral), 4 (agree), 5 (strongly agree). The data is taken from a questionnaire that has been filled in by the respondents who have been assigned

\section{Concept Of Frame Work}

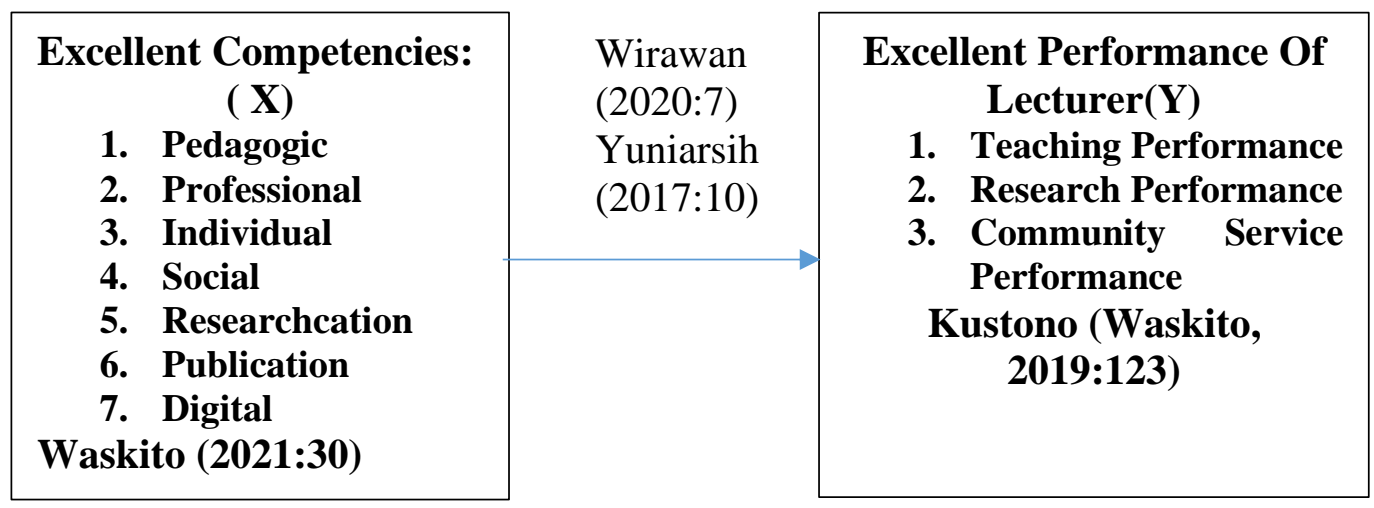


Figure 1.Research Frame Work

\section{The Hypothesis:}

Lecturer's Superior Competence affects Lecturer's Superior Performance

Identifying Variables

1. Independent Variable is Lecturer Superior Competition

2. Dependent Variable is Lecturer Superior Performance

\section{Operational Definition}

1. Lecturer's Superior Competence according to Waskito (2021:29) is the knowledge, attitude, skills, sincerity, humility that a person has in order to complete work quickly, precisely, without mistakes.

2. Lecturer's Superior Competence according to Waskito (2021:29) is the knowledge, attitude, skills, sincerity, humility that a person has in order to complete work quickly, precisely, without mistakes.

\section{Sampling tecnique}

The study used the proportionate stratified simple random sampling method, meaning that all lecturers were given the same opportunity to become respondents regardless of the level of position they had. The researcher applies the proportion of the number of respondents for each study program in accordance with the total population of new students. Sugiyono (2018: 128) explains that the number of samples is determined by the formula: $\mathrm{n}=\mathrm{N}:\{1+\mathrm{N}$ (e) 2 with the information that $\mathrm{n}$ is the number of samples, $\mathrm{N}$ is the number of population (404), e the level of sample error that can be justified is 0.05 . Referring to the opinion of Sugiyono (2018: 128), it can be determined that the number of samples is 201 respondents

\section{Data Analysis Techniques}

The data was analyzed by regression equation and path analysis on AMOS version 23 . . Regression Equation is :

$\mathrm{Y}=\mathrm{a}+\mathrm{b} \mathrm{X}$

Description

1. $X=$ Lecturer Superior Competence

2. $Y=$ Lecturer Superior Performance

3. $\mathrm{a}=$ constant

4. $b=$ regression coefficient

\section{FINDING AND DISCUSSION}

\section{Finding}

The results of this study will present the validity test, reliability test, normality test, description test, regression equation, , hypothesis testing calculated by simple linear regression equations

\section{Validity Test}

Waskito (2020: 38) explains that the validity test is an activity to ensure that researchers have provided opportunities for respondents to state strongly disagree, disagree, quite 
agree, agree and strongly agree, and respondents have used it by providing answers according to respondents' perceptions. about each question posed to the respondent.

Ghazali (2017: 167) explains that the data is declared valid if the variance extracted value is greater than 0.50 . The meaning of the word valid is that the questionnaire has met the requirements as a quality data collection tool.

The meaning of the questionnaire as a quality data collection tool is that the data generated by the questionnaire meets the requirements to be processed with a simple linear regression equation using the AMOS Version 23 application.

The variance extracted formula is the number of squares of standard loading: (number of squares of standard loading + number of squares of measurement error. (Ghazali, 2017: 167). In order to make it easier to calculate and understand the origin of the data, the author presents data on the number of squares estimates and the number of squares of errors for each -each variable is superior competence and superior performance

Table 1. Number of Squares of Standard Loading Dimensions of Superior Competence

\begin{tabular}{|c|c|c|c|c|}
\hline No & Dimensions & Estimate & \multicolumn{2}{|c|}{ Square } \\
\hline 1 & $X 1<-X$ & & 0,566 & 0,32 \\
\hline 2 & $X 2<-X$ & & 0,818 & 0,67 \\
\hline 3 & $X 3<-X$ & & 0,717 & 0,51 \\
\hline 4 & $X 4<-X$ & & 0,883 & 0,78 \\
\hline 5 & $X 5<-X$ & & 0,912 & 0,83 \\
\hline 6 & X6<- X & & 0,886 & 0,78 \\
\hline 7 & $X 7<-X$ & & 0,722 & 0,52 \\
\hline \multicolumn{3}{|r|}{ Total } & & 4,42 \\
\hline
\end{tabular}

Source: Questionnaire (2021), data processed with AMOS Version 23

Table 2. Number of Squares of Errors in Superior Competency Measurement

\begin{tabular}{rlrrr}
\hline No & Dimensions & R Square & Epsilon & \multicolumn{2}{c}{ Epsilon Square } \\
\hline 1 & X1<- X & 0,32 & 0,68 & 0,46 \\
2 & X2<-X & 0,669 & 0,331 & 0,11 \\
3 & X3<- X & 0,506 & 0,494 & 0,24 \\
4 & X4<- X & 0,78 & 0,22 & 0,05 \\
5 & X5<- X & 0,832 & 0,168 & 0,03 \\
6 & X6<- X & 0,786 & 0,214 & 0,05 \\
7 & X7<- X & 0,521 & 0,479 & 0,23 \\
\hline \multicolumn{5}{c}{ Total } \\
\hline
\end{tabular}

Source: Questionnaire (2021), data processed with AMOS Version 23

The value of variance extracted for the superior competence variable is: $4.42:(4.42$ $+1.17)=4.42: 5.59=0.791$. This information shows that the value of variance extracted superior competence is $>0.5$. It means that the data on the superior competence variable is valid data

The author calculates the value of the square of the standard loading for superior performance, the results of which are presented in the table below: 
Table 3. Number of Squares of Standard Loading Dimensions of Superior Performance

\begin{tabular}{rlrrr}
\hline No & Dimensions & Estimate & \multicolumn{2}{c}{ Square } \\
\hline 1 & Y1<- Y & & 0,65 & 0,45 \\
2 & Y2<- Y & & 0,634 & 0,42 \\
3 & Y3<- Y & & 0,563 & 0,33 \\
\hline & & Total & 1,20 \\
\hline
\end{tabular}

Source: Questionnaire (2021) data processed using AMOS Version 23.

Table 4. Number of Squares of Error in Superior Performance Measurement

\begin{tabular}{|c|c|c|c|c|}
\hline No & Dimensions & R Square & Epsilon & Epsilon Square \\
\hline 1 & $X 1<-X$ & 0,423 & 0,577 & 0,28 \\
\hline 2 & $X 2<-X$ & 0,403 & 0,597 & 0,32 \\
\hline 3 & $X 3<-X$ & 0,317 & 0,683 & 0,41 \\
\hline \multicolumn{4}{|c|}{ Total } & 1,01 \\
\hline
\end{tabular}

Source: Questionnaire (2021), data processed using AMOS Version 23

The value of variance extracted for the superior performance variable is: $1.20:(1.20$ $+1.01)=1.20: 2.21=0.54$. This information shows that the superior performance variance extracted value is $>0.5$, meaning that the data on the superior performance variable is valid data. Valid data shows that the questionnaire meets the requirements as a quality data collection tool

\section{Reliability Test}

Waskito (2020: 64) explained that reliability testing is an activity to ensure that respondents provide answers that are fixed, consistent, whether the questions on this questionnaire were asked yesterday, today, and tomorrow.

Ghazali (2017: 166) explains that if the Construct Reliability value is $>0.700$, then the data in the study is declared reliable. The value of construct reliability can be obtained by the formula (Sum of standard loading )2 : (sum of standard loading) $2+$ Total measurement error

Table 5. (Number of Standard Loading) Superior Competencies

\begin{tabular}{rlr} 
No & Dimensions & Estimate \\
\hline 1 & X1<-X & 0,566 \\
2 & X2<-X & 0,818 \\
3 & X3<-X & 0,717 \\
4 & X4<-X & 0,883 \\
5 & X5<-X & 0,912 \\
6 & X6<-X & 0,886 \\
7 & $X 7<-X$ & 0,722 \\
\hline & & 5,504 \\
\hline & Total & 30,294016 \\
\hline
\end{tabular}

Source: Questionnaire (2021) data processed with AMOS Version 23 
The information in table 5 explains that the number of squares of standard loading is 30 , 294

The author collects data on the number of measurement errors (epsilon) of the superior competence variable from the dimensions of the superior competence variable, as presented in table 6 .

Table 6. Number of Measurement Errors (Epsilon) Superior Competency Variables

\begin{tabular}{rlrr}
\hline No & Dimensions & R Square & Epsilon \\
\hline 1 & X1<- X & 0,32 & 0,68 \\
2 & X2<- X & 0,669 & 0,331 \\
3 & X3<- X & 0,506 & 0,494 \\
4 & X4<- X & 0,78 & 0,22 \\
5 & X5<- X & 0,832 & 0,168 \\
6 & X6<- X & 0,786 & 0,214 \\
7 & X7<- X & 0,521 & 0,479 \\
\hline & & & 2,586 \\
\hline
\end{tabular}

Source: Questionnaire (2021) data processed with AMOS Version 23

The information in table 6 explains that the number of errors in the measurement of the superior competence variable is 2,586.

Using the information in table 5 and table 6 , the authors calculate the construct reliability value for the superior competence variable with the results of 30.294: (30.294 $+2.586)=0.921$. This means that 0.921 is greater of 0.700 , because it is greater than 0.700 then all data on the superior competence variable is declared reliable.

The meaning of reliable is that the respondent gives consistent answers, whether the question was asked yesterday, today and tomorrow. The existence of reliable data proves that the questionnaire qualifies as a collecting tool quality data.

Next, the author calculates the construct reliability value of the superior performance variable whose data comes from table 7 and table 8 .

The information in Table 7 explains that the number of standard loading squares of superior performance from lecturers at the Management Study Program at the Private University in Bandung Metropolitan is 3.41

Table 7. Number of Squares of Superior Performance Standard Loading

\begin{tabular}{rlrr}
\hline No & Dimensions & Estimate & \\
\hline 1 & Y1<- Y & & 0,65 \\
2 & Y2<-Y & & 0,634 \\
3 & Y3<- Y & & 0,563 \\
\hline \multicolumn{2}{c}{ Total Sum Of Square } & & 1,847 \\
\hline \multicolumn{2}{r}{} & 3,41 & \\
\hline
\end{tabular}

Source: Questionnaire (2021), data processed with AMOS Version 23 
Table 8. Value of Total Measurement Error (Epsilon) Superior Performance

\begin{tabular}{rlrrr}
\hline No & Dimensions & R Square & Epsilon & \\
\hline 1 & X1<- X & & 0,76 & 0,24 \\
2 & X2<- X & & 0,35 & 0,65 \\
3 & X3<- X & 0,54 & 0,46 \\
\hline & & & 1,35 \\
\hline
\end{tabular}

Source: Questionnaire (2021) data processed with AMOS Version 23

Taking into account the data in table 7 and table 8, the authors calculated the construct reliability value of superior performance with the following results: $3.41:(3.41+1.35)=$ 3.41: $4.76=0.716$ which is higher than 0.700 This means that the data on the superior performance variable is declared reliable. If all data are declared valid and reliable, it can be proven that the questionnaire is a quality data collection tool.

\section{Normality Test}

Table 9. Normality Test

\begin{tabular}{lrrrrrr}
\hline Variable & min & $\max$ & skew & c.r. & kurtosis & c.r. \\
\hline Y1.3 & 1,000 & 5,000 &,- 241 & $-1,397$ &,- 642 & $-1,859$ \\
Y1.2 & 1,000 & 5,000 &,- 194 & $-1,123$ &,- 792 & $-2,292$ \\
Y1.1 & 1,000 & 5,000 &,- 124 &,- 716 &,- 941 & $-2,722$ \\
X1.1 & 1,000 & 5,000 &,- 202 & $-1,168$ &,- 628 & $-1,817$ \\
X1.2 & 1,000 & 5,000 &,- 311 & $-1,797$ &,- 779 & $-2,254$ \\
X1.3 & 1,000 & 5,000 &,- 314 & $-1,815$ &,- 800 & $-2,314$ \\
X1.4 & 1,000 & 5,000 &,- 148 &,- 857 &,- 721 & $-2,087$ \\
X1.5 & 1,000 & 5,000 &,- 147 &,- 849 &,- 699 & $-2,024$ \\
X1.6 & 1,000 & 5,000 &,- 234 & $-1,357$ &,- 766 & $-2,217$ \\
X1.7 & 1,000 & 5,000 &,- 294 & $-1,703$ &,- 779 & $-2,253$ \\
\hline Multivariate & & & & & 17,254 & 7,895 \\
\hline
\end{tabular}

Source: Questionnaire (2021), data processed with AMOS Version 23

Haryono (2021:65) states that the value of cr in the normality test processed with AMOS Version 23 if it produces a value of $-2.58<\mathrm{cr}<2.58$, then the data is declared to have been normally distributed. smaller than 2.58 and greater than -2.58 , then with reference to the opinion of Haryono (2021: 65) the data is declared to have been normally distributed.

\section{Goodness Of Fit}

Table 10. Goodness Of Fit

\begin{tabular}{lllll}
\hline No & $\begin{array}{l}\text { Goodness Of Fit } \\
\text { Criteria }\end{array}$ & Hasil & Cut Off Value & Decision \\
\hline 1 & Chi-Square & 11,33 & $<48$ & Good Fit \\
2 & Probability & 0,067 & $>0,05$ & Good Fit \\
3 & Cmin/ DF & 0,62 & $<2$ & Good Fit \\
4 & RMSEA & 0,042 & $<0,08$ & Good Fit \\
5 & TLI & 0,905 & $>0,90$ & Good Fit \\
\hline
\end{tabular}




\begin{tabular}{cllll}
\hline 6 & NFI & 0,902 & $>0,90$ & Good Fit \\
7 & IFI & 0,929 & $>0,90$ & Good Fit \\
8 & CFI & 0,918 & $>0,90$ & Good Fit \\
9 & PNFI & 0,682 & $>0,6-0,9$ & Good Fit \\
10 & ECVI & $0,908<$ &,$<$ ECVI & Good Fit \\
& & 6,380 & saturated and & \\
& & Independence & \\
& & Model & \\
\hline
\end{tabular}

Source: Questionnaire (2021), data processed with AMOS Version 23

Ghazali (2017: 63) explains that goodness of fit is an activity to ensure there is a match between the data studied and the research model proposed by the researcher in the researcher. There are 3 (three) types of goodness of fit measurement, namely: absolute fit of measure, incremental fit of measure, parsimonious fit measures.

Absolute fit of measure consists of chi square measurement, probability value, RMSEA. Incremental Fit Measures is done by measuring TLI, NFI, IFI, CFI. Parsimonious Fit Measures consist of PNFI, ECVI.

The author conducted a goodness of fit test, the results are presented in the table 10.Latan (2021:49) explains that only 4 or 5 criteria can be met, then the data can be referred to as data that is in accordance with the research model being studied, provided that each criterion already represents the goodness of fit criteria from absolute fit criteria, incremental fit criteria, parsimony fit criteria.

The results of this study indicate that of the 10 required Goodness Of Fit Criteria, all 10 criteria have been met, meaning that the data in the study are in accordance with the research model being studied

\section{Simple Linear Regression Equation Superior Competence Against Superior Performance}

The Effect of Superior Competence on Superior Performance can be seen di figure 1. 


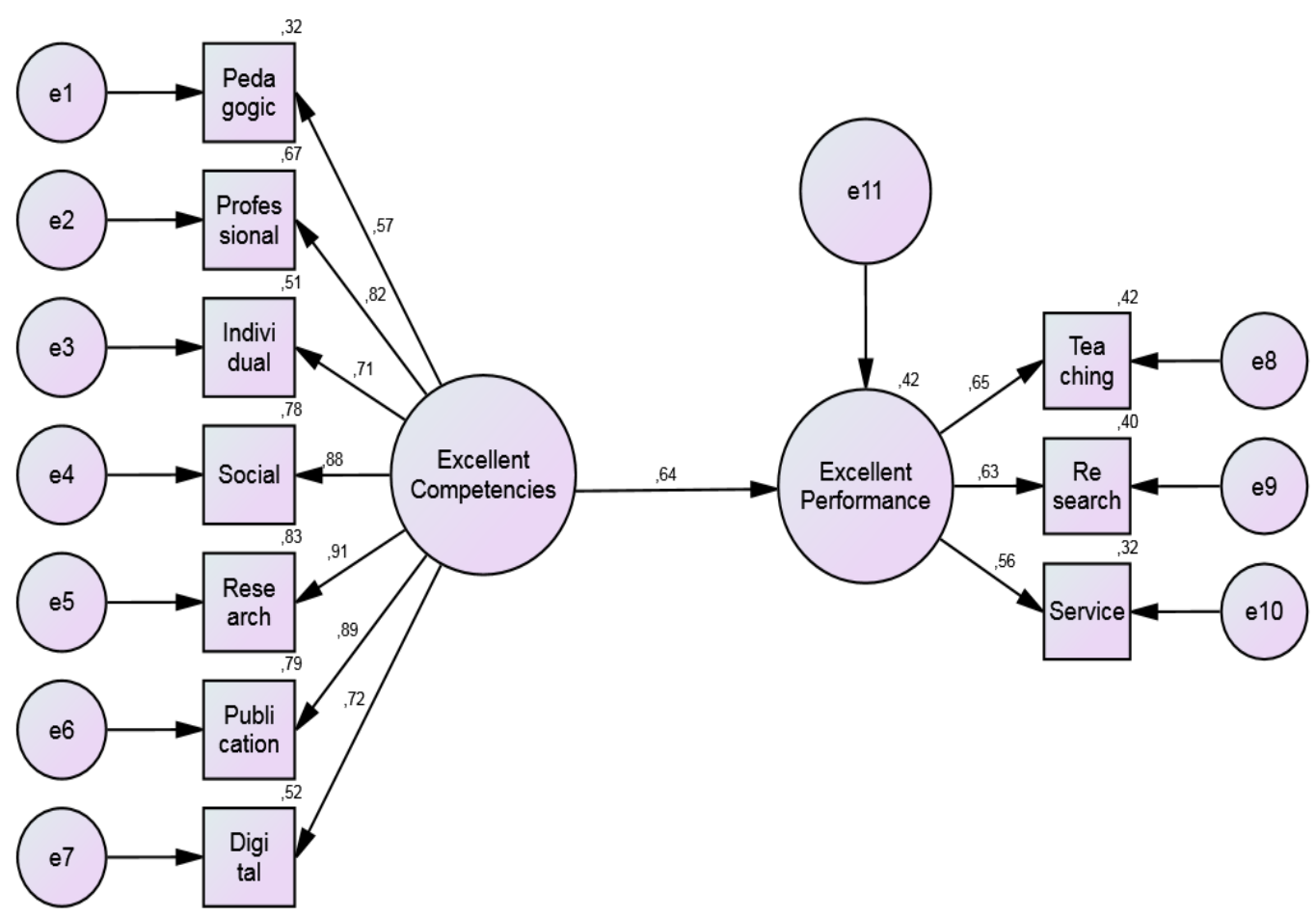

\section{Figure 1. The Effect of Superior Competence on Superior Performance}

Simple linear regression equation using SEM which is processed using the AMOS application version 23 according to Ghazali (2017: 88) as follows

$\mathrm{Y}=\mathrm{a}+\mathrm{b} \mathrm{X}$

$Y=$ Superior Performance

$\mathrm{a}=$ constant

$\mathrm{b}=$ regression coefficient (seen from the estimate on the standardized regression weight line)

$\mathrm{X}=$ Superior Competent

In this study, the value of a was 0.717 and $b$ was 0.644 . So the simple linear regression equation is $\mathrm{Y}=0.717+0.644 \mathrm{X}$. This means that superior performance gets a value of 0.717 if there is no superior competence, but after adding 0.644 superior competency units, it only produces 0.717 superior performance units plus 0.644 to 1,361 .

The calculation results show that the path coefficient value of superior competence on superior performance is 0.644 . In the probability value there is a $* * * * *$ value, which means a probability value of 0.0000 . So there is a positive and significant effect of superior competence on superior performance.

\section{The Influence of Superior Competency Dimensions on Superior Competency Variables}

The information in table 11 explains the magnitude of the influence of the dimensions of superior competence on the variable of superior competence. 
Table 11. The Influence of Competency Dimensions on Superior Competence Variables

\begin{tabular}{lrrr}
\hline & Dimensions & Estimate \\
\hline X1.7 & $<---~ X$ &, 722 \\
X1.6 & $<---~ X$ &, 887 \\
X1.5 & $<---~ X$ &, 914 \\
X1.4 & $<---~ X$ &, 884 \\
X1.3 & $<---~ X$ &, 710 \\
X1.2 & $<---~ X$ &, 813 \\
X1.1 & $<---~ X$ &, 568 \\
\hline
\end{tabular}

Source: Questionnaire, data processed with AMOS Version 23

The dimension of superior competence that gives the greatest influence is X1.5, namely research competence with an influencing contribution value of 0.914 .

The dimension of superior competence that contributes the least to the superior competence of a lecturer is X1.1, namely pedagogic competence which has an average value of 0.568 .

In connection with the value of the pedagogical competence of the lecturers Obtaining the smallest value, the lecturers should improve their pedagogical competence by learning to communicate effectively with students, practicing using teaching and learning process methods that are more in line with online teaching and learning activities , so that the knowledge conveyed by lecturers are easier to understand by students. The position of each competency dimension in influencing superior competence is presented in the picture 


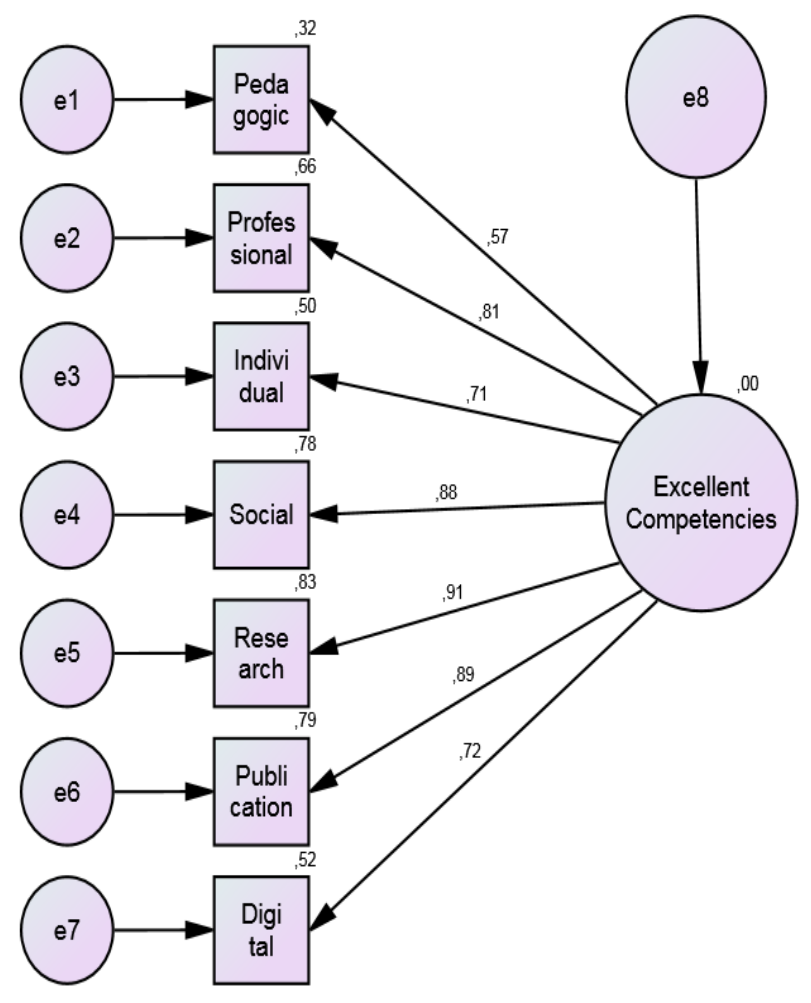

Figure 2. The Influence of Competency Dimensions on Superior Competence Variables

The Influence of Superior Performance Dimensions on Superior Performance Variables

Table 12. The Influence of Superior Performance Dimensions on Superior Performance Variables

\begin{tabular}{rrrr}
\hline & & Dimensions & Estimate \\
\hline $\mathrm{Y} 1.1<--$ & $\mathrm{Y}$ & &, 808 \\
$\mathrm{Y} 1.2<---$ & $\mathrm{Y}$ & &, 557 \\
$\mathrm{Y} 1.3<---$ & $\mathrm{Y}$ & &, 491 \\
\hline
\end{tabular}

Source: Questionnaire (2021), data processed with AMOS Version 23

The information in table 12 explains that the performance dimension that gets the greatest value is teaching performance with a value of 0.808 . The performance dimension that received the smallest value was the performance of community service with a value of 0.491. This information explains that if you want to improve the superior performance of 
lecturers, what must be improved first is the performance in the field of community service, because the performance of community service gets the smallest value. in the village of each lecturer. The solution to this problem is presented in the form of a written report, and published in a community service journal. In this way the lecturer's performance in the field of community service is officially recorded by the journal, and is considered to have met the requirements as a lecturer's performance in the field of community service. The magnitude of the influence of the superior performance dimension on the lecturer's superior performance variable can be presented in the picture

Figure 3. The Influence of Superior Performance Dimensions on Superior Performance Variables

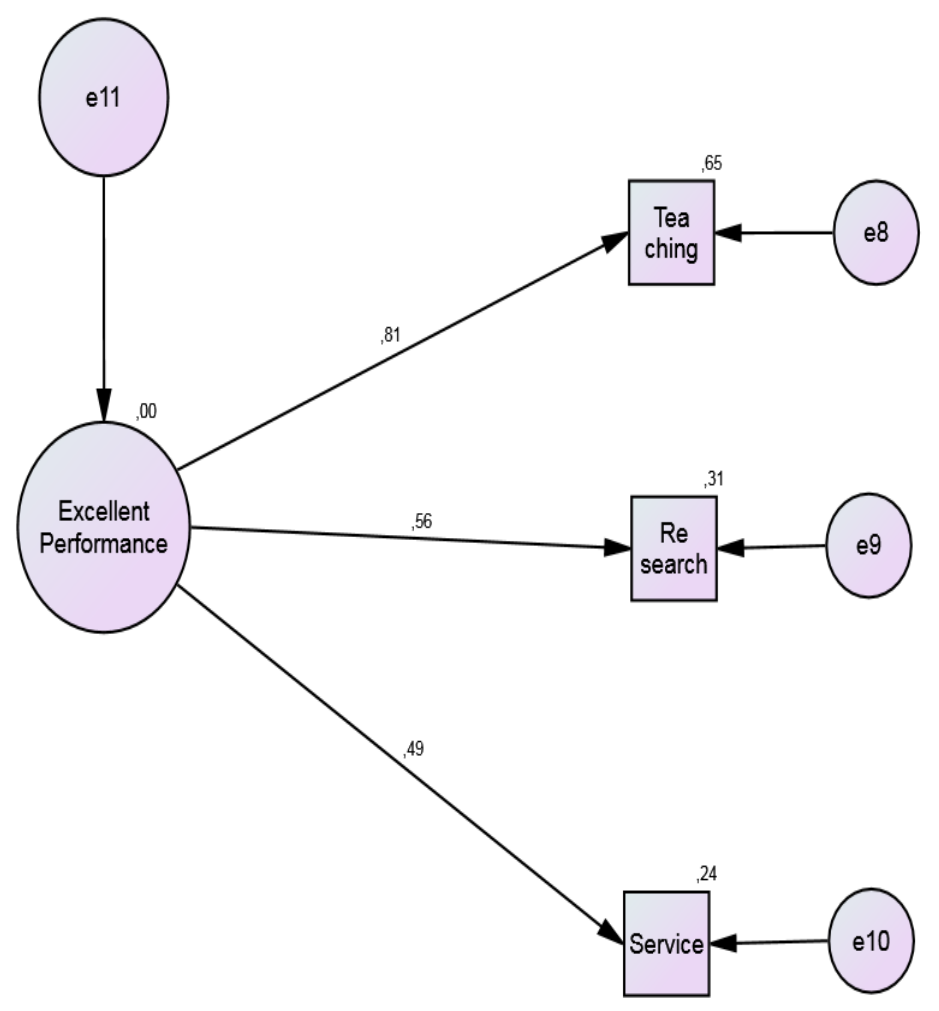

\section{Figure 3. The Influence of Superior Performance Dimensions on Superior Performance Variables}

\section{DISCUSSION}

The author succeeded in proving the positive and significant influence of superior competence of lecturers on superior performance of lecturers, with an estimate value of 0.64 meaning that it has a positive influence and a probability value of $0.0000<0.05$ meaning that it has a significant effect. The results of this study are in line with the opinion expressed by Yuniarsih (2017:10) which explains that the superior performance of lecturers is influenced by the competence of the lecturers, as well as the opinion of Wirawan (2020: 7) which states that competence affects individual performance. In 
connection with that, to improve the superior performance of lecturers, what must be improved first is the superior competence variable, because superior competence is an independent variable in charge of influencing the superior performance of lecturers which is the dependent variable (which is influenced). superior performance of lecturers. Improvement of the superior competence of lecturers is carried out by improving the dimensions of pedagogic competence. Improvement of pedagogic competence is carried out by learning to communicate effectively with students, practicing using teaching and learning process methods that are more in line with online teaching and learning activities, so that the knowledge conveyed by lecturers is more easily understood by students. the smallest is the performance of community service.

The improvement of community service performance is carried out by lecturers creating ideas to solve problems that exist in each lecturer's village. The solution to this problem is presented in the form of a written report, and published in a community service journal. Through this method the lecturer's performance in the field of community service is officially recorded by the journal, and is considered to have met the requirements as a lecturer's performance in the field of community service.

\section{CONCLUSION AND RECOMMENDATION}

\section{Conclusion}

The author has proven that there is a positive and significant influence of superior competence of lecturers on superior performance of lecturers with an estimate value of 0.640 and a probability value of 0.000 .

\section{Recommendation}

In connection with the superior competence proven to affect the superior performance of lecturers, what must be improved first is the superior competence variable, because the superior competence variable is an independent variable in charge of influencing the superior performance of lecturers which is the dependent variable (which is influenced). After improving the superior competence, then improving the superior performance of the lecturer. Improvement of the superior competence of lecturers is carried out by improving the dimensions of pedagogic competence. Improvement of pedagogic competence is carried out by learning to communicate effectively with students, practicing using teaching and learning process methods that are more in line with online teaching and learning activities, so that the knowledge conveyed by lecturers is more easily understood by students. the smallest is the performance of community service.

The improvement of community service performance is carried out by lecturers creating ideas to solve problems that exist in each lecturer's village. The solution to this problem is presented in the form of a written report, and published in a community service journal. Through this method the lecturer's performance in the field of community service is officially recorded by the journal, and is considered to have met the requirements as a lecturer's performance in the field of community service. 


\section{BIBLIOGRAPHY}

Ghozali. (2017). Model Persamaan Struktural Konsep dan Aplikasi AMOS. Semarang: Universitas Diponegoro.

Haryono. (2021). Structural Equation Model Menggunakan AMOS 18. Bekasi: Intermedia Personalia Utama.

Latan. (2021). Structural Equation Model Dengan Aplikasi Lisrel 8.80. Bandung: Alfabeta.

Waskito, S. K. (2021). The Role Digital Competence On The Lecturer Performance Of S1 Accountancy Study Program Of Private Universities In Bandung Metropolitan Area Through Work Satisfaction with Servant Leadership as Moderating Variable. Dinasti International Journal Of Management Science, sept 2021 , Vol 3 No 1, 1-13.

Waskito. (2019). Pengaruh Kepemimpinan Pelayanan, Kompetensi, Motivasi Terhadap Komitmen Afektif Serta Implikasinya Pada Kinerja Dosen Program Studi S1 Akuntansi Se Bandung Raya. Bandung: Doktor Ilmu Manajemen Universitas Pasundan.

Waskito. (2020). Terampil Mengolah Data Statistik Pakai SPSS dan AMOS. Bandung: Alfabeta.

Yuniarsih. (2017). Kinerja Unggul Sumber Daya Manusia. Bandung: Rizqi. 